\title{
CO-COMPOSTING LIMBAH PADAT BELTPRESS DAN JERAMI PADI DENGAN AERATED STATIC PILE
}

\section{CO-COMPOSTING OF BELTPRESS SOLID WASTE AND RICE STRAW BY USING AERATED STATIC PILE}

\author{
Nastiti Siswi Indrasti ${ }^{*}$, Muhammad Romli, Illah Sailah, Astridia Permatasari \\ Departemen Teknologi Industri Pertanian, Fakultas Teknologi Pertanian, Institut Pertanian Bogor \\ Kampus IPB Darmaga, Jl. Raya Dramaga, Bogor, Indonesia \\ Email: nastitiindrasti@yahoo.co.id
}

Makalah: Diterima 14 Oktober 2016; Diperbaiki 10 Januari 2017; Disetujui 20 Januari 2017

\begin{abstract}
Solid waste from beltpress machine in wastewater treatment plant is produced as much as 1,25 tons/day but hasnot been utilized, causing unpleasant odour and requires a high cost for disposal. Composting is one of alternative technology that can be applied to solve the problem. The objectives of this research were to examine the influence of the initial $C / N$ value and aeration rate to the rate of co-composting process in reaching the C/N value that corresponds to SNI 19-7030-2004, and to characterize the compost produced. The research design used was factorial Complete Random Design (CRD) with two factors and two repetitions. The first factor was $C / N$ value, consisted of 25; 30; 35 and the second factor was aeration rate, consisted of 0; 0,4; 0,8 L/min. $\mathrm{kg}$ of dry material. Composting was done using 30 L reactor by giving active intermittent aeration for 1 hour/day during the first 7 days of composting. Effects of initial $C / N$ value and aeration rate were significantly different $(P<0.05)$ in the increase of temperature and the decline of water content and $C / N$ value, but were not significantly different $(P>0.05)$ on $\mathrm{pH}$ value. Lower initial $C / N$ value and higher aeration rate attained standard $C / N$ value fastest. The best treatment based on the conformity with SNI 19-7030-2004 was initial C/N25 with aeration rate 0,8 L/minute.kg dry matter. The compost produced met the SNI standards in macro elements, trace elements, and other elements, but didnot qualify the $\mathrm{pH}$ value and moisture content.
\end{abstract}

Keywords: aerated static pile, beltpress solid waste, co-composting, rice straw

\section{ABSTRAK}

Limbah padat dari mesin beltpress dihasilkan sebanyak 1,25 ton/hari namun sampai saat ini belum termanfaatkan, menimbulkan bau tidak sedap dan membutuhkan biaya besar untuk pembuangannya. Pengomposan merupakan teknologi yang dapat diaplikasikan untuk mengatasi hal tersebut. Penelitian ini bertujuan untuk menguji pengaruh faktor nilai $\mathrm{C} / \mathrm{N}$ awal dan laju aerasi terhadap kecepatan proses co-composting limbah padat beltpress dan jerami padi dalam mencapai nilai C/N sesuai SNI 19-7030-2004, serta mengetahui karakteristik kompos yang dihasilkan. Rancangan acak lengkap faktorial (3x3) yang digunakan terdiri dari faktor nilai $\mathrm{C} / \mathrm{N}$ dengan 3 taraf yaitu 25; 30; 35 dan laju aerasi dengan 3 taraf yaitu 0;0,4;0,8 L/menit.kg bahan kering, sebanyak 2 kali ulangan. Pengomposan dilakukan menggunakan reaktor $30 \mathrm{~L}$ dengan pemberian aerasi selama 1 jam/hari pada 7 hari pertama pengomposan. Hasil ANOVA menunjukkan pengaruh nilai $\mathrm{C} / \mathrm{N}$ awal dan laju aerasi berbeda nyata $(\mathrm{P}<0,05)$ terhadap suhu, kadar air, dan nilai $\mathrm{C} / \mathrm{N}$, tetapi tidak berbeda nyata $(\mathrm{P}>0,05)$ terhadap nilai $\mathrm{pH}$. Semakin rendah nilai $\mathrm{C} / \mathrm{N}$ awal dan semakin tinggi laju aerasi, semakin cepat mencapai nilai C/N sesuai SNI 19-7030-2004. Perlakuan terbaik berdasarkan kesesuaian dengan SNI 19-7030-2004 yaitu C/N awal 25 dengan laju aerasi 0,8 L/menit.kg bahan kering, yang memenuhi syarat SNI bagian fisik (warna, tekstur, bau), unsur makro, unsur mikro dan unsur lainnya, tetapi tidak memenuhi syarat nilai pH dan kadar air.

Kata kunci : aerated static pile, limbah padat beltpress, co-composting, jerami padi

\section{PENDAHULUAN}

Limbah padat beltpress merupakan padatan hasil koagulasi limbah cair pabrik pemotongan ayam dan pengolahan daging ayam dengan menggunakan polyaluminium chloride (PAC), $\mathrm{NaOH}$ dan polimer anionik pada mesin Dissolved Air Flotation (DAF), yang ditekan dengan mesin beltpress. Limbah tersebut dihasilkan sejumlah 1,25 ton/hari pada total produksi 155 ton produk/hari, namun selama ini penanganannya diserahkan ke pihak ketiga sehingga memerlukan biaya besar. Limbah tersebut mengandung bahan organik berupa protein, lemak dan karbohidrat dalam konsentrasi tinggi (Formentini et al., 2010) sehingga dapat dilakukan peningkatan nilai manfaat limbah.

Salah satu alternatif pengolahan limbah organik dalam jumlah besar adalah pengomposan, karena meminimalkan timbunan limbah melalui dekomposisi dan mengurangi gas hasil perombakan anaerob yang membahayakan kesehatan (Indrasti, 2015). Nilai $\mathrm{C} / \mathrm{N}$ bahan merupakan faktor penting 
karena dekomposer memerlukan sejumlah karbon dan nitrogen untuk pertumbuhannya. Girovich (1996) menyatakan limbah rumah potong unggas memiliki nilai C/N 5-10, sementara menurut Asian Development Bank (2011), nilai C/N ideal bahan pengomposan berkisar 25-40, sehingga limbah membutuhkan sumber karbon. Jerami padi memiliki nilai C/N 70 (Karki dan Dixit, 1984) dan tersedia melimpah di Indonesia (1 hektar lahan sawah menghasilkan 5-8 ton jerami) namun pemanfaatannya baru $38 \%$ (Harahap, 2010), sehingga dapat berperan sebagai sumber karbon tambahan.

Selain itu, pelaksanaan pengomposan di industri membutuhkan waktu yang singkat agar tidak terjadi akumulasi bahan. Laju aerasi merupakan faktor penting dalam pengomposan (Diaz et al., 2002). Aerasi terlalu sedikit menyebabkan kondisi anaerobik, namun aerasi terlalu banyak menurunkan laju pengomposan karena terbuangnya panas, air dan amonia. Oleh karena itu, dilakukan penelitian untuk menguji pengaruh nilai $\mathrm{C} / \mathrm{N}$ awal dan laju aerasi terhadap kecepatan proses co-composting limbah padat beltpress dan jerami padi dalam mencapai nilai C/N yang sesuai SNI 19-7030-2004, serta mengetahui karakteristik kompos yang dihasilkan.

\section{BAHAN DAN METODE}

\section{Alat dan Bahan}

Peralatan yang digunakan yaitu reactor pengomposan (Agastirani, 2011), kompressor, flow meter, pipa, saringan ukuran 25 mesh, selang, termometer, $\mathrm{pH}$ meter, timbangan analitik, stopwatch, oven, tanur, kompor listrik, distiller kjedahl, inkubator, dan atomic absorbtion spectrofotometer $(A A S)$. Bahan yang digunakan yaitulimbah padat beltpress, jerami padi, $\mathrm{H}_{2} \mathrm{SO}_{4}$, $\mathrm{NaOH}$, etanol 95\%, $\mathrm{H}_{3} \mathrm{BO}_{3}, \mathrm{Na}_{2} \mathrm{SO}_{4}, \mathrm{HNO}_{3}$, $\mathrm{CuSO}_{4} .5 \mathrm{H}_{2} \mathrm{O}, \mathrm{SnCl}_{2}$, ammonium heptamolibdat, aquades, indikator mengsell, indikator phenolptalein, indikator metil orange, gliserol, n-heksan, kertas saring dan kapas.

\section{Karakterisasi dan Formulasi Bahan Baku}

Karakterisasi limbah padat beltpress meliputi kadar air, abu, lemak, serat kasar, protein dan karbohidrat (AOAC, 1984), karbon organik metode by difference sesuai JICA (1978) dan total kjedahl nitrogen (APHA, 2012). Karakterisasi jerami meliputi kadar karbon organik dan total kjedahl nitrogen. Berdasarkan hasil karakterisasi, dilakukan formulasi bahan untuk mengetahui bobot masingmasing bahan agar mencapai nilai $\mathrm{C} / \mathrm{N}$ awal campuran sebesar 25, 30 dan 35, dengan total bobot campuran sebesar $4 \mathrm{~kg}$ bahan kering. Formulasi tersebut dilakukan dengan menghitung menggunakan rumus berikut (Djuarnani et al., 2005).
Pengomposan selama 60 hari dilakukan meggunakan tangki $30 \mathrm{~L}$ yang diisi campuran bahan limbah padat beltpress dan cacahan jerami (ukuran 1 inci) sesuai hasil tahap formulasi bahan. Selama 7 hari pertama, tumpukan bahan diberi aerasi aktif dari kompressor selama 1 jam/hari, dengan laju sebesar 0; 0,4; dan 0,8 L/menit.kg bahan kering.

Selama pengomposan, kadar air bahan dijaga sekitar 50-60\%. Pengontrolan kadar air dilakukan dengan memeras segenggam bahan dari bagian dalam tumpukan. Apabila air keluar 1-2 tetes / tangan menjadi basah, kelembaban dianggap cukup / sekitar 50-60\%. Apabila air tidak keluar, tumpukan terlalu kering / kurang dari 30\%. Jika tumpukan terlalu kering, ditambahkan air dan jika terlalu basah, tumpukan dibalik. Pencegahan kekeringan pada awal pengomposan dilakukan dengan penambahan air 5\% total massa awal setiap minggu dari minggu ke-1 sampai ke-4 (Warsito dalam Hermawan, 2015).

Selain kadar air, dilakukan pengukuran suhu melalui 3 titik lubang sampel setiap hari. Adapun pengukuran lainnya dilakukan setiap 2 minggu meliputi pH (SNI 06-6989.11-2004), kadar air (AOAC, 1984), kadar karbon (JICA, 1978) dan total kjedahl nitrogen (APHA, 2012).

\section{Karakterisasi Produk Kompos}

Karakterisasi seluruh produk kompos dilakukan untuk mengetahui kualitas kompos yang dihasilkan dari berbagai perlakuan, yang meliputi parameter warna, ukuran partikel, bau, kadar karbon, kadar nitrogen, nilai $\mathrm{C} / \mathrm{N}$, kadar air, nilai $\mathrm{pH}$ dan suhu, dengan mengacu pada SNI 19-7030-2004. Perlakuan terbaik dipilih berdasarkan jumlah parameter yang paling banyak memenuhi syarat SNI. Kompos dengan perlakuan terbaik kemudian dikeringkan dengan cara dijemur untuk mecegah terjadinya perubahan karakteristik menjelang pelaksanaan uji lanjutan yang meliputi kadar air, kandungan unsur makro (kadar bahan organik, kadar karbon, kadar nitrogen, nilai $\mathrm{C} / \mathrm{N}$, kadar phospor/ $\mathrm{P}_{2} \mathrm{O}_{5}$, kadar kalium $/ \mathrm{K}_{2} \mathrm{O}$ ), kandungan unsur mikro (As, Cd, $\mathrm{Co}, \mathrm{Cr}, \mathrm{Cu}, \mathrm{Hg}, \mathrm{Ni}, \mathrm{Pb}, \mathrm{Se}, \mathrm{Zn}$ ), kandungan unsur lainnya (Ca, Mg, Fe, Al, Mn) (APHA 2012) dan jumlah bakteri patogen Escherichia coli serta Salmonella sp. (SNI 01-2891-1992).

\section{Analisis dan Pengolahan Data}

RAL faktorial $(3 \times 3)$ in timeyang digunakan terdiri dari2 faktor perlakuan, yaitu laju aerasi dan nilai $\mathrm{C} / \mathrm{N}$ awal, dan 2 ulangan. Laju aerasi terdiri dari 3 taraf yaitu $0 ; 0,4 ; 0,8 \mathrm{~L} /$ menit.kg bahan kering. Nilai C/N awal terdiri dari 3 taraf yaitu 25;30;35. Data hasil percobaan diolah menggunakan ANOVA untuk mengetahui pengaruh perlakuan dengan tingkat kepercayaan 95\% $(\pi=0,05)$. Apabila berpengaruh nyata dilanjutkan dengan uji Duncan.

Nilai $\mathrm{C} / \mathrm{N}=\frac{(\% C \text { limbah padat beltpress } x \text { bobot limbah }) x(\% C \text { jerami } x \text { bobot jerami })}{(\% N \text { limbah padat beltpress } x \text { bobot limbah }) x(\% N \text { jerami } x \text { bobot jerami })}$ 


\section{HASIL DAN PEMBAHASAN}

Pengomposan adalah proses dekomposisi dan stabilisasi bahan organik secara biologis pada kondisi terkontrol dengan hasil akhir berupa karbondioksida, air dan produk dalam bentuk padatan komplek yang bersifat stabil sehingga tidak menimbulkan efek merugikan terhadap lingkungan apabila diberikan pada lahan (Haug, 1980). Cocomposting adalah pengomposan yang menggunakan lebih dari 1 bahan baku untuk meningkatkan laju degradasi dan kualitas produk kompos yang dihasilkan, dimana umumnya bahan yang dipadukan adalah biosolid/sludge dengan limbah padat organik (Indrasti, 2015). Biosolid menjadi sumber nitrogen dan menjaga kelembaban, sedangkan limbah padat digunakan sebagai bahan pencampur yang memiliki kandungan karbon organik yang tinggi dan bersifat kamba sehingga memudahkan sirkulasi udara.

Pada dasarnya proses pengomposan adalah suatu proses biologis, yang menunjukkan bahwa peran mikroorganisme pengurai sangat besar. Oleh karena itu prinsip pengomposan adalah menciptakan kondisi yang mendukung pertumbuhan populasi mikroorganisme pengurai untuk mempercepat stabilisasi bahan organik. Dengan demikian kondisi yang mempengaruhi pertumbuhan mikroorganisme pengurai menjadi faktor yang mempengaruhi pengomposan. Faktor-faktor yang mempengaruhi pengomposan terdiri dari ukuran bahan, porositas, nilai $\mathrm{C} / \mathrm{N}$, kadar air, suhu, $\mathrm{pH}$ dan aerasi (Bari, 1999). Secara umum, persamaan reaksi dekomposisi bahan organik secara aerob adalah sebagai berikut (Panda, 2013):

$$
\begin{aligned}
& \text { Gula, hemiselulosa, } \quad\left(\mathrm{CH}_{2} \mathrm{O}\right) \mathrm{x}+\mathrm{x}_{2} \rightarrow \mathrm{x} \mathrm{CO}_{2}+\mathrm{x} \mathrm{H}_{2} \mathrm{O} \\
& \text { selulosa, lignin, + energi } \\
& \text { protein } \\
& \text { Nitrogen organik 1. Pembentukan amonium : } \\
& \mathrm{RNH}_{2}+\mathrm{H}^{+}+\mathrm{H}_{2} \mathrm{O} \rightarrow \mathrm{R} \cdot \mathrm{OH}+ \\
& \mathrm{NH}_{4}^{+} \\
& \mathrm{NH}_{4}^{+}+\mathrm{OH}^{-} \rightarrow \mathrm{NH}_{3}+\mathrm{H}_{2} \mathrm{O} \\
& \text { 3. Pembentukan nitrit : } \\
& \mathrm{NH}_{3}+1.5 \mathrm{O}_{2} \rightarrow \mathrm{NO}_{2}^{-}+\mathrm{H}^{+}+ \\
& \mathrm{H}_{2} \mathrm{O} \\
& \text { Atau } \mathrm{NH}_{3}+2 \mathrm{O}_{2} \rightarrow \mathrm{NO}_{3}{ }^{-}+ \\
& \mathrm{H}^{+}+\mathrm{H}_{2} \mathrm{O} \\
& \text { Atau } \mathrm{NO}_{2}^{-}+1 / 2 \mathrm{O}_{2} \rightarrow \mathrm{NO}_{3} \\
& \mathrm{~S} \text { organik }+\mathrm{O}_{2} \rightarrow \mathrm{SO}_{4}{ }^{2-} \\
& \mathrm{P} \text { organik }+\mathrm{O}_{2} \rightarrow \mathrm{H}_{3} \mathrm{PO}_{4} \rightarrow \\
& \mathrm{Ca}\left(\mathrm{HPO}_{4}\right)_{2}
\end{aligned}
$$

Sebelum dilakukan pengomposan, karakteristik limbah padat beltpress dan jerami padi diuji terlebih dahulu untuk memastikan potensi pemanfaatan bahan sebagai bahan baku pengomposan.

\section{Karakteristik dan Formulasi Bahan Baku Karakteristik Bahan Baku}

Kadar air optimum untuk pengomposan sebesar 55\% (Dalzell et al.,1987) sehingga kedua jenis bahan dikeringkan (dijemur) terlebih dahulu. Hasil analisis komposisi limbah padat beltpressyang sudah dikeringkan (Tabel 1) menunjukkan kandungan terbesar limbah padat beltpress adalah lemaksebesar $32,23 \%$ dan protein sebesar $19,35 \%$. Limbah memiliki nilai $\mathrm{C} / \mathrm{N}$ sebesar 9,09, yang tidak termasuk dalam rentang nilai $\mathrm{C} / \mathrm{N}$ ideal untuk pengomposan (sebesar 25-40) menurut Asian Development Bank (2011). Namun hasil ini sesuai pernyataan Girovich (1996) bahwa limbah organik seperti biosolid bersifat lembab dan kaya nitrogen, dengan nilai $\mathrm{C} / \mathrm{N}$ sekitar 5-10.

Efisiensi pengomposan bahan dengan $\mathrm{C} / \mathrm{N}$ di luar rentang optimal lebih baik jika dicampur dengan bahan lain daripada secara tersendiri (Isroi, 2008). Hal ini disebabkan untuk pertumbuhan optimal mikroorganisme pengurai, dibutuhkan 1 bagian nitrogen untuk setiap pengonsumsian 30 bagian karbon dalam bahan organik. Jika $\mathrm{C} / \mathrm{N}$ lebih besar dari rentang tersebut, nitrogen yang tersedia tidak mencukupi kebutuhan nitrogen mikroorganisme sehingga bahan akan terurai lebih lambat. Jika $\mathrm{C} / \mathrm{N}$ lebih rendah dari rentang tersebut, nitrogen berlebih yang tidak digunakan mikroorganisme akan menguap sebagai gas amonia (Haug, 1980). Dengan demikian, limbah padat beltpress sebagai sumber nitrogen membutuhkan bahan yang dapat berfungsi sebagai sumber karbon.

Pada penelitian ini, sumber karbon yang digunakan adalah jerami padi segar. Karakteristik jerami padi disajikan pada Tabel 1. Nilai $\mathrm{C} / \mathrm{N}$ jerami padi sebesar 71,31. Hasil ini tidak berbeda jauh dengan hasil penelitian Abbasi et al. (2002) bahwa nilai $\mathrm{C} / \mathrm{N}$ jerami padi berkisar antara 50-70. Jerami padi memiliki nilai $\mathrm{C} / \mathrm{N}$ yang lebih tinggi daripada limbah padat beltpress karena secara kimia jerami terdiri dari $28-36 \%$ selulosa, $23-28 \%$ hemiselulosa, $12-16 \%$ lignin, dan 15-20\% abu (Mulder, 1996). Dengan demikian, limbah padat beltpress dan jerami padi dapat dikombinasikan agar mencapai nilai $\mathrm{C} / \mathrm{N}$ bahan ideal.

\section{Formulasi Bahan Baku}

Hasil formulasi berdasarkan rumus pada Djuarnani et al. (2005) dengan total bahan baku kompos sebesar $4 \mathrm{~kg}$ berat kering disajikan pada Tabel 2. Tabel 2 menunjukkan semakin tinggi nilai $\mathrm{C} / \mathrm{N}$ yang dituju, semakin banyak jumlah jerami padi yang digunakan. Perbedaan komposisi limbah padat beltpress dan jerami padi pada masing-masing nilai $\mathrm{C} / \mathrm{N}$ awal akan mempengaruhi komposisi kandungan dalam campuran bahan, yang pada akhirnya dapat berdampak pada adanya perbedaan kecepatan pengomposan. 
Tabel 1. Kandungan limbah padat beltpress dan jerami padi

\begin{tabular}{|c|c|c|c|c|}
\hline \multirow{3}{*}{ Analisis } & \multicolumn{4}{|c|}{ Kandungan (\% bb) } \\
\hline & \multicolumn{2}{|c|}{ Limbah padat beltpress } & \multicolumn{2}{|c|}{ Jerami padi } \\
\hline & Segar & Hasil pengeringan & Segar & Hasil pengeringan \\
\hline Kadar air (\%) & $84,04 \pm 0,07$ & $35,71 \pm 0,11$ & $\begin{array}{r}61,66 \pm \\
0,73\end{array}$ & $12,33 \pm 0,07$ \\
\hline Kadar abu (\%) & $2,47 \pm 0,05$ & $9,94 \pm 0,04$ & $4,74 \pm 0,11$ & $10,84 \pm 0,02$ \\
\hline Kadar protein $(\%)$ & $4,80 \pm 0,35$ & $19,35 \pm 0,50$ & $1,59 \pm 0,48$ & $3,66 \pm 0,28$ \\
\hline Kadar lemak (\%) & $8,00 \pm 0,01$ & $32,23 \pm 0,04$ & & \\
\hline Kadar serat $(\%)$ & $0,66 \pm 0,05$ & $2,64 \pm 0,05$ & & \\
\hline Kadar karbohidrat (by & 0,03 & 0,13 & & \\
\hline difference) & & & & \\
\hline Kadar C-Organik (\%) & 6,99 & 28,16 & 18,32 & 41,89 \\
\hline Total kjedahl nitrogen $(\%)$ & $0,77 \pm 0,06$ & $3,10 \pm 0,08$ & $0,26 \pm 0,08$ & $0,59 \pm 0,04$ \\
\hline Nilai $\mathrm{C} / \mathrm{N}$ & 9,10 & 9,09 & 71,62 & 71,31 \\
\hline
\end{tabular}

Tabel 2. Hasil formulasi bahan baku pengomposan

\begin{tabular}{|c|c|c|c|c|c|c|}
\hline \multirow{2}{*}{$\begin{array}{c}\text { Nilai } \mathbf{C} / \mathbf{N} \\
\text { Awal }\end{array}$} & \multicolumn{2}{|c|}{ Massa (kg bk) } & \multirow{2}{*}{$\begin{array}{c}\text { Total Massa } \\
\text { (kg bk) }\end{array}$} & \multicolumn{2}{|c|}{ Massa (kg bb) } & \multirow{2}{*}{$\begin{array}{c}\text { Massa air yang } \\
\text { ditambahkan } \\
(\mathrm{kg})\end{array}$} \\
\hline & $\begin{array}{c}\text { Limbah Padat } \\
\text { Beltpress }\end{array}$ & $\begin{array}{c}\text { Jerami } \\
\text { Padi }\end{array}$ & & $\begin{array}{c}\text { Limbah Padat } \\
\text { Beltpress }\end{array}$ & $\begin{array}{c}\text { Jerami } \\
\text { Padi }\end{array}$ & \\
\hline 25 & 1,15 & 2,85 & 4 & 1,79 & 3,25 & 3,85 \\
\hline 30 & 0,86 & 3,14 & 4 & 1,34 & 3,58 & 3,97 \\
\hline 35 & 0,65 & 3,35 & 4 & 1,01 & 3,82 & 4,06 \\
\hline
\end{tabular}

Pada $\mathrm{C} / \mathrm{N}$ awal 25, limbah padat beltpress yang digunakan paling banyak sehingga kandungan lemak dan proteinnya lebih tinggi. Sementara itu pada $\mathrm{C} / \mathrm{N}$ awal 35, jerami padi yang digunakan paling banyak sehingga kandungan lignoselulosanya lebih tinggi.

\section{Perubahan Selama Co-composting} Suhu

Kalor sebagai hasil dekomposisi bahan organik (Metcalf dan Eddy, 1991) meningkatkan suhu bahan selama pengomposan. Perubahan suhu itu sendiri mempengaruhi metabolisme dan dinamika populasi mikroba. Perubahan suhu ratarata selama pengomposan disajikan pada Gambar 1 . Menurut Herdiyantoro (2010), proses pengomposan terdiri atas tiga tahapan dalam kaitannya dengan suhu, yaitu degradasi awal/mesofilik $\left(24-45^{\circ} \mathrm{C}\right)$, termofilik $\left(>45^{\circ} \mathrm{C}\right)$, pendinginan dan pematangan.

Berdasarkan Gambar 1 (a), (b), (c), suhu laju aerasi $0,4 \mathrm{~L} / \mathrm{menit} . \mathrm{kg}$ bahan kering paling tinggi, sedangkan laju aerasi $0 \mathrm{~L} / \mathrm{menit} . \mathrm{kg}$ bahan paling rendah. Hasil uji Duncan menunjukkan suhu perlakuan laju aerasi $0,4 \mathrm{~L} /$ menit.kg bahan kering berbeda nyata lebih tinggi daripada perlakuan lainnya. Suhu laju aerasi 0 dan $0,8 \mathrm{~L} /$ menit.kg bahan kering tidak berbeda nyata.

Menurut Dalzell et al. (1987), dalam pengomposan diperlukan udara yang cukup ke semua bagian tumpukan untuk memasok oksigen pada mikroorganisme dan mengeluarkan karbondioksida yang dihasilkan. Aerasi yang terlalu sedikit menyebabkan kondisi menjadi anaerobik akibat kekurangan oksigen. Energi yang dihasilkan dari dekomposisi 1 molekul glukosa secara anaerobik sebesar 2 ATP dengan panas metabolik yang hilang ke lingkungan sebesar $70 \%$, sedangkan dari dekomposisi aerobik sebesar 38 ATP dengan panas metabolik yang hilang sebesar $68 \%$ (Kleidon, 2005). Rendahnya panas metabolik dari kondisi anaerobik menyebabkan suhu pengomposan rendah. Sementara itu aerasi berlebihan dapat meningkatkan biaya dan menurunkan laju pengomposan karena tingginya kehilangan panas, air dan amonia (Diaz et al., 2002). Laju aerasi optimum tergantung komposisi bahan baku dan metode pemberian udara (Guo et al., 2012). Hal ini menunjukkan perlakuan laju aerasi $0,4 \mathrm{~L} /$ menit.kg bahan kering merupakan laju aerasi yang optimum untuk suhu pengomposan limbah padat beltpress dan jerami padi.

Berdasarkan Gambar 1 (d), (e), (f), C/N awal 25 menunjukkan suhu paling rendah pada awal pengomposan, sebab kandungan karbon organik mudah terurai pada $\mathrm{C} / \mathrm{N}$ awal 25 paling sedikitdan memiliki volume tumpukan paling kecil sehingga panas yang dihasilkan tidak tertahan. Sementara itu perlakuan $\mathrm{C} / \mathrm{N}$ awal 30 memliki suhu maksimal tertinggi. Setelah minggu ke-2 pengomposan, perlakuan $\mathrm{C} / \mathrm{N}$ awal 25 memiliki suhu yang lebih tinggi. Hal ini dapat disebabkan oleh baru terjadinya penguraian bahan lignoselulosa dan lemak akibat suhu pengomposan sebelumnya lebih rendah. Meskipun demikian, suhu $\mathrm{C} / \mathrm{N}$ awal 25 paling cepat mencapai kestabilan pada suhu SNI 19-7030-2004, kecuali pada laju aerasi $0 \mathrm{~L} / \mathrm{menit} . \mathrm{kg}$ bahan kering. Hasil ANOVA menunjukkan pengaruh nilai $\mathrm{C} / \mathrm{N}$ awal tidak berbeda nyata $(\mathrm{P}>0,05)$ terhadap suhu selama pengomposan. Hal ini menunjukkan perbedaan komposisi bahan tidak mempengaruhi suhu. 


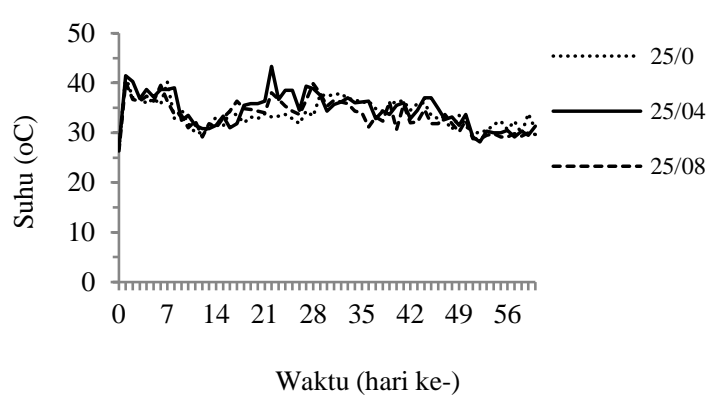

(a)

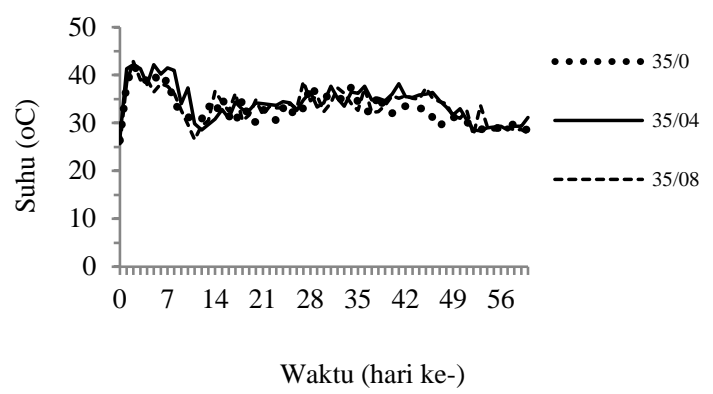

(c)

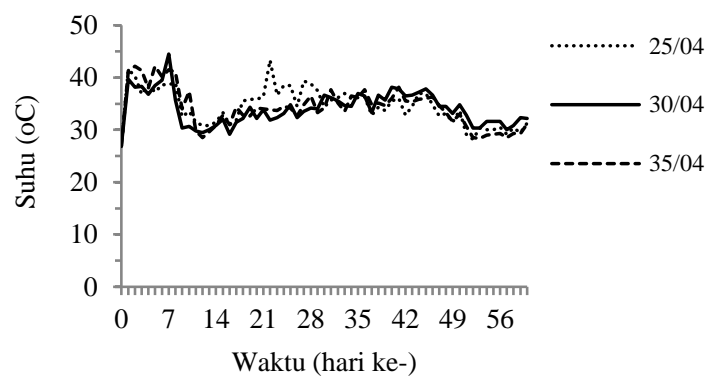

(e)

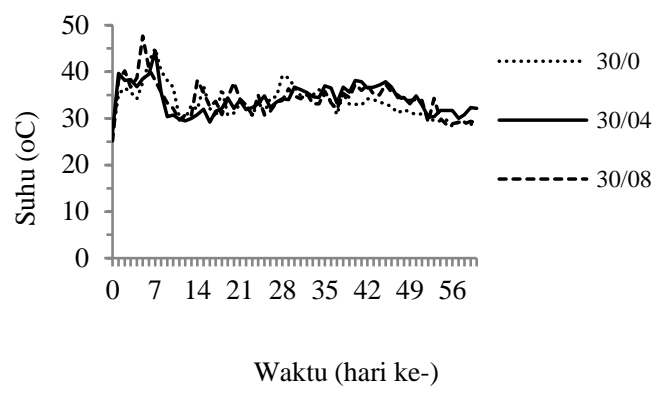

(b)

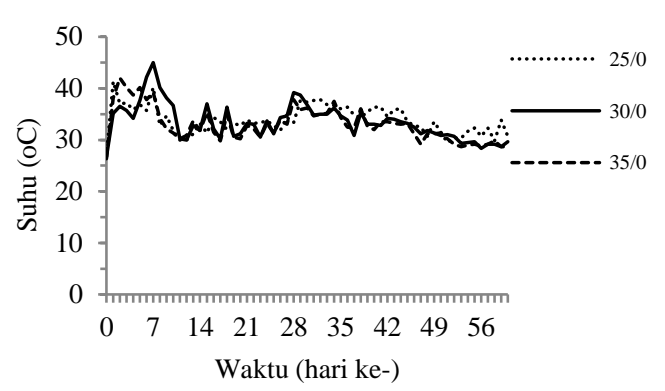

(d)

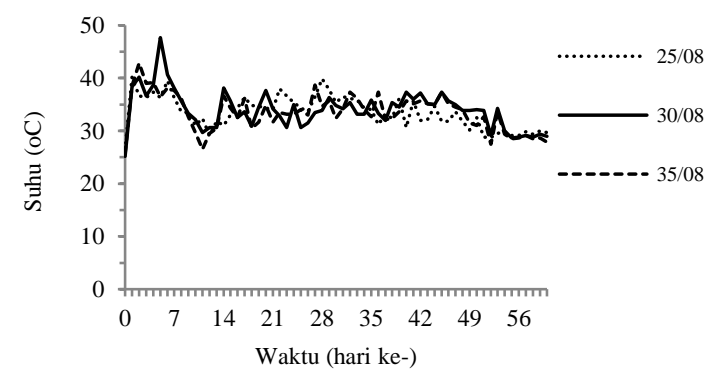

(f)

Gambar 1. Perubahan suhu pada $\mathrm{C} / \mathrm{N}$ awal (a) 25, (b) 30,(c) 35 untuk berbagai laju aerasi, dan pada laju aerasi (d) $0 \mathrm{~L} /$ menit.kg bahan kering, (e) 0,4L/menit.kg bahan kering, (f) $0,8 \mathrm{~L} /$ menit.kg bahan kering untuk berbagai $\mathrm{C} / \mathrm{N}$ awal

Hasil ANOVA juga menunjukkan interaksi $\mathrm{C} / \mathrm{N}$ awal dengan laju aerasi tidak berpengaruh nyata $(\mathrm{P}>0,05)$ terhadap suhu. Hal ini menunjukkan faktor $\mathrm{C} / \mathrm{N}$ awal dan laju aerasi tidak sinergis dalam perubahan suhu. Secara keseluruhan, berdasarkan hasil ANOVA, laju aerasi berpengaruh nyata terhadap suhu pengomposan sementara nilai $\mathrm{C} / \mathrm{N}$ awal dan interaksi keduanya tidak berpengaruh nyata. Hal ini menunjukkan bahwa nilai $\mathrm{C} / \mathrm{N}$ awal tidak perlu diterapkan karena tidak meningkatkan efektivitas. Namun laju aerasi yang paling optimum, yaitu $0,4 \mathrm{~L} /$ menit.kg bahan kering perlu untuk diterapkan.

\section{Derajat Keasaman (pH)}

Nilai $\mathrm{pH}$ mempengaruhi kelarutan berbagai zat kimia dengan mempengaruhi derajat ionisasi senyawa kimia tersebut, sehingga pada akhirnya juga mempengaruhi ketersediaan nutrisi untuk mikroba pengurai, aktivitas populasi mikroba dan toksisitas beberapa bahan yang dikandung bahan. Nilai $\mathrm{pH}$ optimum pengomposan berkisar antara 5,5 dan 8,0 (Bertoldi et al., 1983). Pada rentang $\mathrm{pH}$ tersebut, nutrisi untuk pertumbuhan mikroorganisme pengurai tersedia paling tinggi karena berada dalam bentuk terdisosiasi. Pada $\mathrm{pH}$ di bawah 5,5, nutrisi menjadi kurang tersedia dan beberapa mikronutrien dapat menjadi racun karena bersifat toksik dalam bentuk tidak terdisosiasi. Pada $\mathrm{pH}$ di atas 8, pembentukan amonia (bersifat toksik) lebih tinggi.

Nilai $\mathrm{pH}$ awal bahan sebesar 8.Nilai $\mathrm{pH}$ berubah selama pengomposan karena adanya perubahan komposisi kimia (Beck-Friis et al., 2003). Pada minggu ke-2 nilai $\mathrm{pH}$ meningkatsampai kisaran 8,7-9, selanjutnya menurun pada minggu-minggu berikutnya sampai kisaran $8,3-8,8$ pada minggu ke8.Berdasarkan hasil pengamatan terhadap suhu (Gambar 3 dan 4), fase degradasi maksimal ditandai dengan aktivitas mikrobial tertinggi, yaitu pada hari ke-1 sampai 8. Menurut Bolan et al. (2003), pada fase tersebut terjadi dekomposisi protein, lemak, selulosa dan hemiselulosa. Sebagian nitrogen 
organik (protein) di substrat diubah secara mikrobial menjadi biomassa mikroba dan sebagian lagi dimineralisasi menjadi gas amonium $\left(\mathrm{NH}_{4}{ }^{+}\right)$dengan menggunakan ion $\mathrm{H}^{+}$pada persamaan reaksi $\mathrm{RNH}_{2}+$ $\mathrm{H}^{+}+\mathrm{H}_{2} \mathrm{O} \rightarrow \mathrm{R} \cdot \mathrm{OH}+\mathrm{NH}_{4}^{+}$, sehingga nilai $\mathrm{pH}$ meningkat sampai kisaran 7-9 (Bishop dan Godfrey, 1983). Hal inilah yang menjadi penyebab peningkatan nilai $\mathrm{pH}$ pada minggu ke-2 pengomposan.

Setelah minggu ke-2, penurunan nilai $\mathrm{pH}$ terjadi karena adanya volatilisasi amonia, nitrifikasi dan reaksi antara karbondioksida yang dihasilkan dari proses degradasi aerob dengan air pada bahan dengan persamaan reaksi (Bolan et al., 2003) :

$$
\begin{aligned}
& \text { Volatilisasi amonia : } \mathrm{NH}_{4}{ }^{+}+\mathrm{OH}^{-} \rightarrow \mathrm{NH}_{3} \text { (menguap) } \\
& +\mathrm{H}_{2} \mathrm{O} \\
& \text { Reaksi karbondioksida dan air : } \mathrm{CO}_{2}+\mathrm{H}_{2} \mathrm{O} \rightarrow \\
& \mathrm{H}_{2} \mathrm{CO}_{3} \rightarrow \mathrm{H}^{+}+ \\
& \mathrm{HCO}_{3}
\end{aligned}
$$

Nitrifikasi :

1. Pembentukan nitrit : $\mathrm{NH}_{3}+1.5 \mathrm{O}_{2} \rightarrow \mathrm{NO}_{2}{ }^{-}+$ $\mathrm{H}^{+}+\mathrm{H}_{2} \mathrm{O}$

2. Pembentukan nitrat :

$\mathrm{NH}_{4}{ }^{+}+2 \mathrm{O}_{2} \rightarrow \mathrm{NO}_{3}{ }^{-}+\mathrm{H}_{2} \mathrm{O}+2 \mathrm{H}^{+}$

Atau $\mathrm{NH}_{3}+2 \mathrm{O}_{2} \rightarrow \mathrm{NO}_{3}{ }^{-}+\mathrm{H}^{+}+\mathrm{H}_{2} \mathrm{O}$

Atau $\mathrm{NO}_{2}^{-}+1 / 2 \mathrm{O}_{2} \rightarrow \mathrm{NO}_{3}$

Ion amonium $\left(\mathrm{NH}_{4}^{+}\right)$dalam media basa terdisosiasi menjadi gas amonia $\left(\mathrm{NH}_{3}\right)$ yang mudah menguap. Menurut Moore et al. (1997) volatilisasi $\mathrm{NH}_{3}$ meningkat ketika nilai $\mathrm{pH}$ di atas 7,0. Reaksi tersebut menurunkan nilai $\mathrm{pH}$ karena adanya penggunaan ion $\mathrm{OH}^{-}$saat perubahan $\mathrm{NH}_{4}{ }^{+}$menjadi $\mathrm{NH}_{3}$. Adapun reaksi nitrifikasi dan disosiasi $\mathrm{H}_{2} \mathrm{CO}_{3}$ menghasilkan ion $\mathrm{H}^{+}$sehingga menurunkan nilai $\mathrm{pH}$ pula (Bolan et al., 2003). Selain itu, seiring berjalannya waktu pengomposan juga dihasilkan asam humat dan fulvat sehingga menurunkan nilai pH mendekati netral. Sementara itu kandungan abu, karbonat dan senyawa-senyawa bersifat basa lainnya berfungsi sebagai buffer dan menjaga nilai $\mathrm{pH}$ dari penurunan yang terlalu besar (Eklind dan Kirchmann, 2000). Pencapaian nilai pH antara 8,0 dan 9,0 menunjukkan bahwa proses pengomposan berhasil (Sundberg et al., 2004).

Tingginya nilai $\mathrm{pH}$ awal disertai dengan peningkatan $\mathrm{pH}$ sampai 9,0 dan adanya aktivitas buffer setelahnya menjadi penyebab nilai $\mathrm{pH}$ akhir pengomposan tidak sesuai dengan SNI 19-7030$2004(6,80-7,49)$. Hal ini menunjukkan proses nitrifikasi dan pembentukan $\mathrm{CO}_{2}$ dari proses pengomposan terlalu sedikit untuk dapat menyeimbangkan amonium yang dihasilkan, sehingga juga menunjukkan bahwa suplai oksigen yang diberikan terlalu sedikit, karena pemberian aerasi hanya dilakukan selama 1 jam/hari pada 7 hari pertama pengomposan dan pembalikan bahan setiap 2 minggu sekali.
Laju aerasi $0 \mathrm{~L} / \mathrm{menit.kg}$ bahan kering memiliki nilai $\mathrm{pH}$ paling rendah. Hal ini dapat disebabkan jumlah oksigen yang tersedia paling rendah karena hanya berasal dari porositas bahan, sehingga reaksi yang terjadi adalah $\mathrm{C}_{6} \mathrm{H}_{12} \mathrm{O}_{6}+1 \frac{1}{2}$ $\mathrm{O}_{2} \rightarrow \mathrm{C}_{6} \mathrm{H}_{8} \mathrm{O}_{7}$ (asam sitrat) $+2 \mathrm{H}_{2} \mathrm{O}$ dan $\mathrm{C}_{6} \mathrm{H}_{12} \mathrm{O}_{6}+1$ $1 / 2 \mathrm{O}_{2} \rightarrow 3 \mathrm{C}_{2} \mathrm{H}_{2} \mathrm{O}_{4}$ (asam oksalat) $+3 \mathrm{H}_{2} \mathrm{O}$ (Bolan et al. 2003). Dihasilkannya asam-asam tersebut, menurunkan nilai $\mathrm{pH}$. Hal ini didukung Beck-Friis $e t$ al. (2003) bahwa pada bahan yang tidak diberikan aerasi yang cukup, produksi asam lebih besar dan disertai dengan penguraian (oksidasi) asam yang lebih lambat bila dibandingkan dengan kompos yang diberikan aerasi yang cukup. Jika aerasi yang diberikan cukup untuk mensuplai oksigen, reaksi yang terjadi adalah $\mathrm{C}_{6} \mathrm{H}_{12} \mathrm{O}_{6}+6 \mathrm{O}_{2} \rightarrow 6 \mathrm{CO}_{2}+6$ $\mathrm{H}_{2} \mathrm{O}$ (Bolan et al. 2003). Adapun nilai $\mathrm{pH}$ tertinggi selama pengomposan dihasilkan oleh perlakuan laju aerasi 0,8 L/menit.kg bahan kering, Hal ini menunjukkan produksi amonium paling tinggi karena lebih tingginya suplai oksigen yang diberikan pada awal pengomposan.Hasil ANOVA menunjukkan pengaruh laju aerasi tidak berbeda nyata terhadap nilai $\mathrm{pH}(\mathrm{P}>0,05)$.Hal ini menunjukkan hasil kesetimbangan berbagai zat yang diperoleh dari dekomposisi seluruh laju aerasi hampir sama.

Hasil penelitian juga menunjukkan semakin rendah nilai $\mathrm{C} / \mathrm{N}$ awal, nilai $\mathrm{pH}$ semakin tinggi, sebab semakin banyak nitrogen organik pada bahan, semakin tinggi amonium yang dihasilkan sehingga nilai pH nya tinggi (Rynk, 2003). Sebaliknya, semakin tinggi nilai $\mathrm{C} / \mathrm{N}$ awal, nilai $\mathrm{pH}$ semakin rendah, sebab semakin banyak kandungan karbon, semakin banyak karbondioksida yang dihasilkan dari penguraiannya. Larutnya karbondioksida dalam air membentuk ion karbonat dan ion $\mathrm{H}^{+}$yang menurunkan nilai $\mathrm{pH}$ (Weast et al., 1990).Hasil ANOVA menunjukkan pengaruh $\mathrm{C} / \mathrm{N}$ awaltidak berbeda nyata terhadap nilai $\mathrm{pH}(\mathrm{P}>0,05)$. Hal ini menunjukkan hasil kesetimbangan zat yang diperoleh dari dekomposisi keseluruhan perlakuan $\mathrm{C} / \mathrm{N}$ awal sama. Hasil ANOVA juga menunjukkan pengaruh interaksi nilai $\mathrm{C} / \mathrm{N}$ awal dan laju aerasi tidak berbeda nyata terhadap nilai $\mathrm{pH}(\mathrm{P}>0,05)$. Hal ini menunjukkan faktor nilai $\mathrm{C} / \mathrm{N}$ awal dan laju aerasi tidak sinergis dalam perubahan $\mathrm{pH}$.

Secara keseluruhan, laju aerasi, nilai $\mathrm{C} / \mathrm{N}$ awal dan interaksi keduanya tidak berpengaruh nyata terhadap nilai $\mathrm{pH}$ pengomposan, sehingga menunjukkan bahwa dari segi nilai $\mathrm{pH}$ pengomposan, ketiganya tidak perlu diterapkan karena tidak meningkatkan efektivitas.

\section{Kadar Air}

Menurut Djaja (2008) kadar air bahan baku kompos sebaiknya berkisar antara 40-65\%. Menurut Dalzell et al. (1987), kadar air optimum untuk pengomposan sebesar 55\%. Kondisi kadar air tersebut menunjang proses metabolik 
mikroorganisme dalam mendegradasi bahan organik. Jika kadar air di bawah $40 \%$ akan mengakibatkan aktivitas mikroba dalam mendegradasi bahan organik menjadi lambat karena proses metabolismenya terhambat. Bahkan pada kadar air kurang dari $15 \%$, aktivitas mikroorganisme terhenti (Rynk et al., 1992). Jika lebih dari 65\% akan mengakibatkan air menutupi rongga udara sehingga aliran oksigen berkurang. Akibatnya, kondisi menjadi anaerobik dan pertumbuhan mikroorganisme aerob menjadi terhambat.

Pada awal pengomposan kadar air campuran bahan diatur hingga menjadi 55\%. Dinamika perubahan kadar air dapat dilihat pada Gambar 2. Berdasarkan Gambar 2, kadar air seluruh perlakuan meningkat sampai minggu ke-4 selanjutnya menurun sampai minggu ke-8. Degradasi bahan organik secara oksidasi akan menghasilkan $\mathrm{CO}_{2}$, energi (panas) dan air sehingga meningkatkan kadar air (Herdiyantoro, 2010). Adanya penurunan kadar air merupakan hasil kesetimbangan massa air, dimana air dari hasil degradasi bahan organik lebih sedikit daripada air yang hilang melalui proses evaporasi (Cahyani, 2013). Dihasilkannya air bersamaan dengan energi panas dari dekomposisi menyebabkan kadar air ditentukan dari hasil kesetimbangan antara keduanya. Berdasarkan SNI 19-7030-2004, kadar air kompos maksimal 50\%. Pada penelitian ini tidak ada perlakuan yang mencapai nilai tersebut saat akhir pengomposan disebabkan olehadanya penambahan air sebesar 5\% total massa awal sampai minggu ke-4 pengomposan namun tidak diiringi dengan tingginya suhu pengomposan.

Berdasarkan Gambar 2 diketahui semakin tinggi laju aerasi, peningkatan kadar air semakin kecil. Hal ini dapat disebabkan oleh paling rendahnya suhu pengomposan perlakuan laju aerasi $0 \mathrm{~L} /$ menit.kg bahan kering daripada perlakuan lainnya. Sementara itu laju aerasi $0,8 \mathrm{~L} / \mathrm{menit} . \mathrm{kg}$ bahan kering memiliki peningkatan kadar air paling kecil karena adanya evaporasi air yang lebih tinggi akibat pemberian udara yang lebih banyak. Hasil ANOVA menunjukkan terdapat pengaruh berbeda nyata dari perlakuan laju aerasi terhadap perubahan kadar air $(\mathrm{P}<0,05)$. Uji lanjut Duncan menunjukkan ketiga laju aerasi berbeda nyata satu sama lain, dengan kadar air laju aerasi $0 \mathrm{~L} /$ menit.kg bahan kering paling tinggi sedangkan laju aerasi 0,8 L/menit.kg bahan kering paling rendah. Hal ini menunjukkan semakin tinggi laju aerasi, semakin rendah kadar air karena evaporasi lebih tinggi dari diberikannya udara yang lebih banyak pada awal pengomposan. Dengan demikian laju aerasi terbaik berdasarkan kadar air yang paling mendekati SNI 19-7030-2004 adalah 0,8 L/menit.kg bahan kering.

Berdasarkan Gambar 2 juga diketahui bahwa semakin tinggi nilai $\mathrm{C} / \mathrm{N}$ awal, kadar air semakin tinggi. Perlakuan $\mathrm{C} / \mathrm{N}$ awal 25 memiliki ukuran volume yang paling kecil sehingga laju penguapan airnya lebih tinggi. Hal ini sesuai dengan pernyataan (O’leary, 1995) bahwa tumpukan kompos dengan volume yang lebih besar memiliki permukaan evaporasi lebih rendah daripada tumpukan kompos dengan volume yang lebih kecil. Adapun peningkatan kadar air C/N 25 paling tinggi saat awal pengomposan disebabkan oleh suhu 7 hari pertama pengomposannya paling rendah. Hasil ANOVA menunjukkan pengaruh nilai $\mathrm{C} / \mathrm{N}$ awalberbeda nyata $(\mathrm{P}<0,05)$ terhadap perubahan kadar air. Hal ini menunjukkan $\mathrm{C} / \mathrm{N}$ awal mempengaruhi kadar air selama pengomposan karena adanya perbedaan komposisi bahan dan volume tumpukan. Uji lanjut Duncan menunjukkan perlakuan $\mathrm{C} / \mathrm{N}$ awal 35 berbeda nyata dengan $\mathrm{C} / \mathrm{N}$ awal lainnya. Sementara itu perlakuan $\mathrm{C} / \mathrm{N}$ awal 25 dan 30 tidak berbeda nyata. Perlakuan $\mathrm{C} / \mathrm{N}$ awal terbaik dari segi kadar air yang mendekati SNI yaitu $\mathrm{C} / \mathrm{N}$ awal 25.

Hasil uji ANOVA menunjukkan pengaruh interaksi antara nilai $\mathrm{C} / \mathrm{N}$ awal dan laju aerasi tidak berbeda nyata $(\mathrm{P}>0,05)$ terhadap kadar air. Hal ini menunjukkan kombinasi laju aerasi dan nilai $\mathrm{C} / \mathrm{N}$ awal yang berbeda menghasilkan kadar air selama pengomposan yang relatif sama. Secara keseluruhanberdasarkan hasil ANOVA, laju aerasi dan nilai $\mathrm{C} / \mathrm{N}$ awal berpengaruh nyata terhadap kadar air sementara interaksi keduanya tidak berpengaruh nyata. Hal ini menunjukkan bahwa dari segi kadar air, fungsi faktor laju aerasi dan nilai $\mathrm{C} / \mathrm{N}$ awal tidak bersifat sinergis sehingga jika diterapkan bersama tidak meningkatkan efektivitas. Namun penerapan secara terpisah dapat meningkatkan efektivitas, sehingga faktor yang perlu diterapkan adalah salah satu di antara keduanya.

\section{Nilai $\mathbf{C} / \mathbf{N}$}

Karbon sebagai sumber energi dan nitrogen sebagai zat pembentuk protoplasma (pembangun sel mikroorganisme) yang terdapat pada bahan baku pengomposan turut menentukan kecepatan pengomposan (Gaur, 1983). Menurut Asian Development Bank (2011), C/N optimum untuk bahan baku pengomposan berkisar antara 25-40. Hal ini disebabkan untuk pertumbuhan optimal mikroorganisme pengurai, dibutuhkan 1 bagian nitrogen untuk setiap pengonsumsian 30 bagian karbon dalam bahan organik. Jika $\mathrm{C} / \mathrm{N}$ lebih besar dari rentang tersebut, nitrogen yang tersedia tidak mencukupi kebutuhan nitrogen mikroorganisme sehingga bahan akan terurai lebih lambat. Jika C/N lebih rendah dari rentang tersebut, nitrogen berlebih yang tidak digunakan mikroorganisme akan menguap sebagai gas amonia (Haug, 1980). Perubahan nilai $\mathrm{C} / \mathrm{N}$ selama pengomposan disajikan pada Gambar 3. 


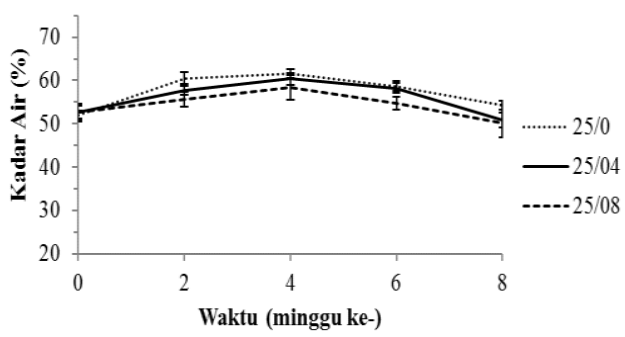

(a)

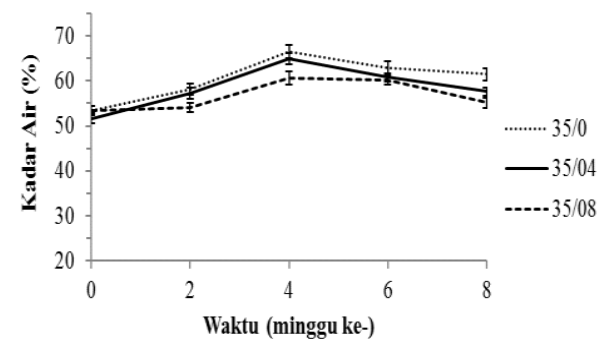

(c)

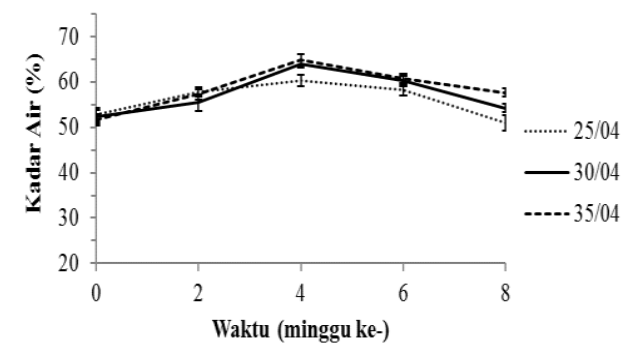

(e)

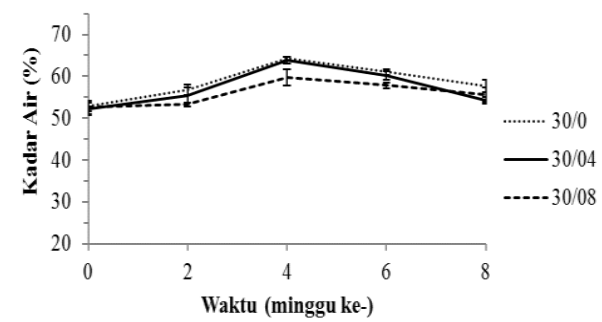

(b)

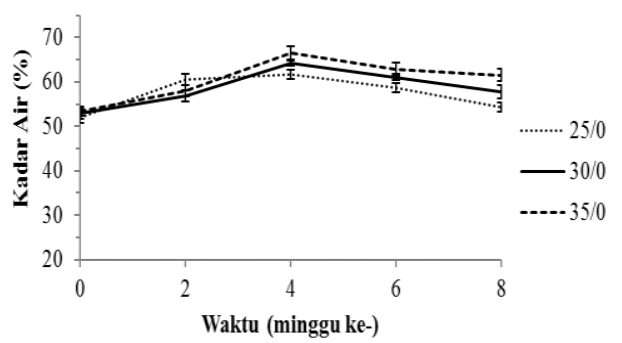

(d)

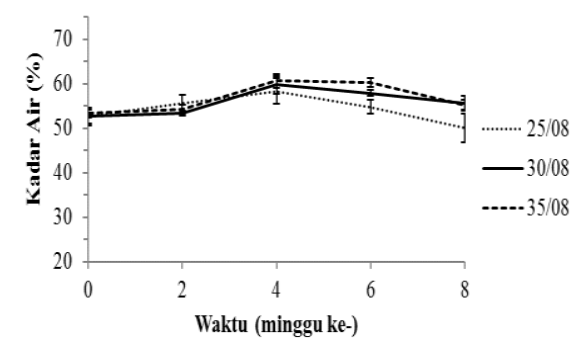

(f)

Gambar 2. Perubahan kadar air selama co-composting pada $\mathrm{C} / \mathrm{N}$ awal (a) 25, (b) 30,(c) 35 untuk berbagai laju aerasi, dan pada laju aerasi (d) $0 \mathrm{~L} /$ menit.kg bahan kering, (e) $0,4 \mathrm{~L} / \mathrm{menit} . \mathrm{kg}$ bahan kering, (f) 0,8 $\mathrm{L} /$ menit.kg bahan kering untuk berbagai $\mathrm{C} / \mathrm{N}$ awal

Berdasarkan Gambar 3, keseluruhan perlakuan mengalami penurunan nilai $\mathrm{C} / \mathrm{N}$ sampai mencapai nilai $\mathrm{C} / \mathrm{N}$ akhir sebesar 13-27. Hal ini sesuai dengan pernyataan Golueke (1972) bahwa nilai $\mathrm{C} / \mathrm{N}$ akan menurun selama pengomposan akibat berkurangnya kadar karbon organik diiringi dengan kadar nitrogen organik yang relatif tetap.Penurunan karbon organik terjadi akibat mineralisasi karbon organik menjadi anorganik (Bernal et al., 1998) dan pelepasan $\mathrm{CO}_{2}$ ke udara sebagai salah satu hasil dekomposisi bahan organik oleh mikroorganisme (Bishop dan Godfrey, 1983).

Berdasarkan Gambar 3, laju aerasi 0 L/menit.kg bahan kering menunjukkan penurunan nilai $\mathrm{C} / \mathrm{N}$ paling sedikit sehingga memiliki kisaran nilai $\mathrm{C} / \mathrm{N}$ akhir paling tinggi yaitu $16-25$. Hasil ANOVA menunjukkan pengaruh laju aerasi berbeda nyata terhadap perubahan nilai $\mathrm{C} / \mathrm{N}(\mathrm{P}<0,05)$. Uji lanjut Duncan menunjukkan ketiga perlakuan laju aerasi berbeda nyata satu sama lain, dengan nilai $\mathrm{C} / \mathrm{N}$ laju aerasi $0 \mathrm{~L} / \mathrm{menit} . \mathrm{kg}$ bahan kering paling tinggi sedangkan laju aerasi $0,8 \mathrm{~L} /$ menit.kg bahan kering paling rendah. Hal ini menunjukkan semakin tinggi laju aerasi,penurunan nilai $\mathrm{C} / \mathrm{N}$ juga semakin besar sehingga mempercepat tercapainya nilai $\mathrm{C} / \mathrm{N}$ yang sesuai SNI 19-7030-2004 dan diperoleh nilai $\mathrm{C} / \mathrm{N}$ akhir yang semakin rendah. Menurut Guo et al. (2012), kebutuhan aerasi pada awal pengomposan sangat besar untuk degradasi bahan organik dan menurun pada tahap selanjutnya. Pemberian aerasi pada awal pengomposan dibutuhkan untuk memperpendek tahap mesofilik awal sehingga tahap termofilik cepat tercapai (Suler dan Finstein, 1977). Selain itu hal ini berkaitan dengan pemberian pasokan oksigen yang lebih banyak pada laju aerasi yang lebih tinggi. Oksigen berperan penting pada pengomposan karena bertindak sebagai penerima elektron (akseptor) dari metabolisme bahan organik untuk menghasilkan energi (ATP) (Stryer, 1995). Semakin banyak dihasilkan energi dari perombakan bahan organik, semakin cepat penurunan nilai $\mathrm{C} / \mathrm{N}$ bahan yang dikomposkan.

Berdasarkan Gambar 3, diketahui bahwa $\mathrm{C} / \mathrm{N}$ awal 25 mengalami penurunan nilai $\mathrm{C} / \mathrm{N}$ yang paling sedikit namun paling cepat stabil (setelah minggu ke-2) pada kisaran nilai $\mathrm{C} / \mathrm{N}$ yang disyaratkan SNI 19-7030-2004, dengan C/N akhir sebesar 15-16. 


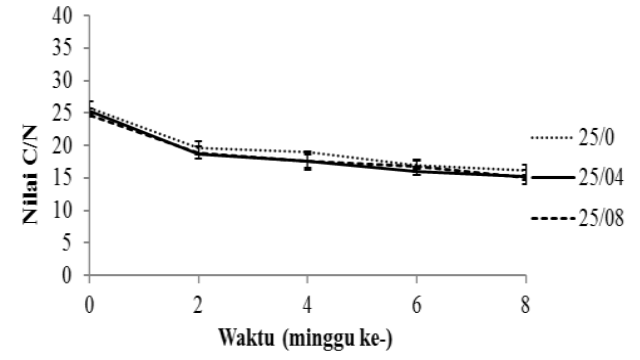

(a)

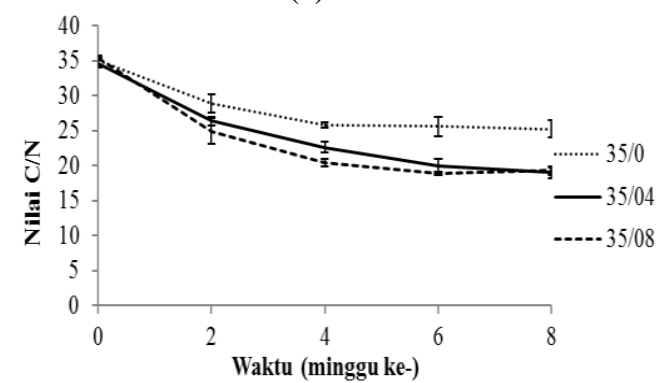

(c)

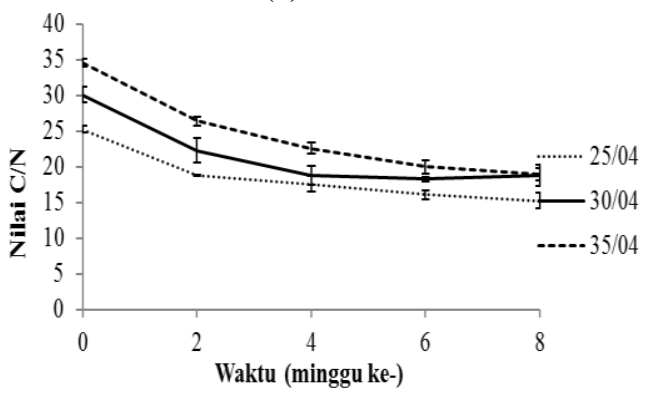

(e)

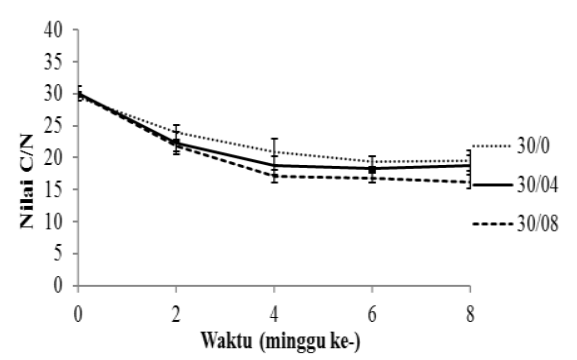

(b)

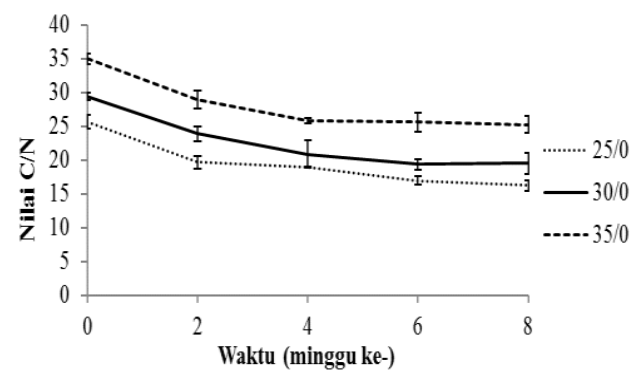

(d)

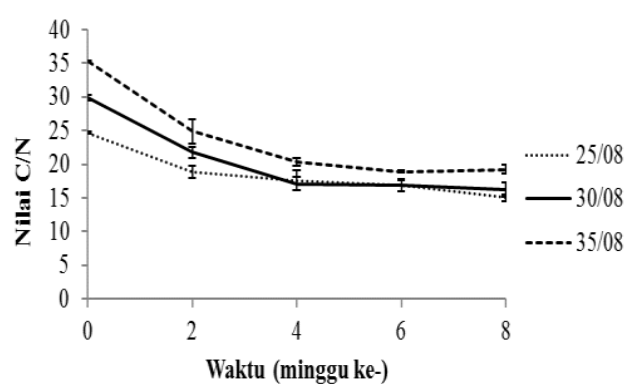

(f)

Gambar 3. Perubahan nilai $\mathrm{C} / \mathrm{N}$ selama co-composting pada $\mathrm{C} / \mathrm{N}$ awal (a) 25 , (b) 30,(c) 35 untuk berbagai laju aerasi, dan pada laju aerasi (d) $0 \mathrm{~L} /$ menit.kg bahan kering, (e) 0,4L/menit.kg bahan kering, (f) 0,8 $\mathrm{L} /$ menit.kg bahan kering untuk berbagai $\mathrm{C} / \mathrm{N}$ awal

Sementara itu $\mathrm{C} / \mathrm{N}$ awal 35 mengalami penurunan nilai $\mathrm{C} / \mathrm{N}$ yang paling banyak namun tidak cepat stabil (stabil setelah minggu ke-6) pada kisaran nilai $\mathrm{C} / \mathrm{N}$ yang disyaratkan SNI 19-70302004, dengan $\mathrm{C} / \mathrm{N}$ akhir sebesar 18-25. Hal ini dapat disebabkan oleh kandungan senyawa karbon organik pada $\mathrm{C} / \mathrm{N}$ awal 25 paling sedikit sedangkan $\mathrm{C} / \mathrm{N}$ awal 35 paling banyak. Selain itu $\mathrm{C} / \mathrm{N}$ awal 25 sendiri sudah mendekati nilai $\mathrm{C} / \mathrm{N}$ sesuai SNI 197030-2004 yang bernilai 20 sehingga waktu yang dibutuhkan untuk pengomposan relatif lebih cepat (Djuarnani et al., 2005).

Hasil ANOVA menunjukkan pengaruh nilai $\mathrm{C} / \mathrm{N}$ awal berbeda nyata terhadap perubahan nilai $\mathrm{C} / \mathrm{N}(\mathrm{P}<0,05)$. Hasil uji Duncan menunjukkan ketiga perlakuan nilai $\mathrm{C} / \mathrm{N}$ awal memberikan pengaruh beda nyata antara satu sama lain, dengan nilai $\mathrm{C} / \mathrm{N}$ pada $\mathrm{C} / \mathrm{N}$ awal 35 paling tinggi sedangkan pada $\mathrm{C} / \mathrm{N}$ awal 25 paling rendah. Hal ini menunjukkan bahwa komposisi bahan mempengaruhi penurunan nilai $\mathrm{C} / \mathrm{N}$. Semakin rendah nilai $\mathrm{C} / \mathrm{N}$ awal, kandungan karbon semakin sedikit sehingga semakin cepat mencapai nilai $\mathrm{C} / \mathrm{N}$ yang sesuai dengan SNI. Dengan demikian, dari segi kecepatan mencapai nilai $\mathrm{C} / \mathrm{N}$ yang stabil pada kisaran nilai $\mathrm{C} / \mathrm{N}$ SNI, perlakuan $\mathrm{C} / \mathrm{N}$ awal terbaik adalah 25. Adapun pengaruh interaksi $\mathrm{C} / \mathrm{N}$ dengan laju aerasi dapat dilihat pada Gambar 4.

Berdasarkan Gambar 4, semakin tinggi nilai $\mathrm{C} / \mathrm{N}$ awal, pemberian aerasi semakin memberikan pengaruh terhadap penurunan nilai $\mathrm{C} / \mathrm{N}$. Uji Duncan menunjukkan bahwa perlakuan $\mathrm{C} / \mathrm{N}$ awal 35 dengan laju aerasi $0 \mathrm{~L} /$ menit.kg bahan kering berbeda nyata dengan perlakuan lainnya. Sementara itu perlakuan lainnya tidak berbeda nyata antara satu dengan yang lain. Hal ini menunjukkan bahwa $\mathrm{C} / \mathrm{N}$ awal 35 membutuhkan pemberian aerasi untuk dapat mencapai nilai $\mathrm{C} / \mathrm{N}$ akhir $10-20$ (sesuai SNI 197030-2004) dalam kurun waktu 8 minggu pengomposan. Sementara itu $\mathrm{C} / \mathrm{N}$ awal 25 dan 30 tidak membutuhkan pemberian aerasi karena hasilnya tidak berbeda nyata dengan yang diberi aerasi. Hal ini disebabkan kandungan karbon organik pada perlakuan $\mathrm{C} / \mathrm{N}$ awal 35 lebih banyak dibandingkan $\mathrm{C} / \mathrm{N}$ awal 25 dan 30 sehingga membutuhkan oksigen yang lebih banyak untuk mendegradasinya. 


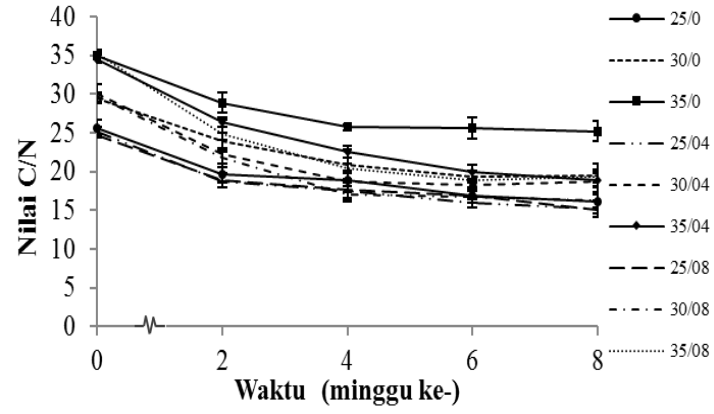

Gambar 4. Perubahan nilai $\mathrm{C} / \mathrm{N}$ pada seluruh perlakuan

Tidak berbeda nyatanya semua interaksi perlakuan kecuali $\mathrm{C} / \mathrm{N}$ awal 35 dengan laju aerasi 0 $\mathrm{L} /$ menit.kg bahan kering menyebabkan kombinasi perlakuan terbaik untuk perubahan nilai $\mathrm{C} / \mathrm{N}$ dipilih melalui kecepatan mencapai nilai $\mathrm{C} / \mathrm{N}$ yang sesuai SNI 19-7030-2004. Interaksi perlakuan terbaik adalah $\mathrm{C} / \mathrm{N}$ awal 25 dengan laju aerasi $0 \mathrm{~L} /$ menit.kg bahan kering. Perlakuan ini mencapai kestabilan pada nilai C/N yang sesuai SNI 19-7030-2004 dalam waktu yang singkat, yaitu mulai 2 minggu pertama pengomposan. Selain itu laju aerasi $0 \mathrm{~L} /$ menit.kg bahan kering pada $\mathrm{C} / \mathrm{N}$ awal 25 ini secara ekonomi lebih efisien karena tidak berbeda nyata dengan diberi aerasi.

Secara umum berdasarkan hasil ANOVA, laju aerasi, $\mathrm{C} / \mathrm{N}$ awal dan interaksi keduanya berpengaruh nyata terhadap nilai $\mathrm{C} / \mathrm{N}$ pengomposan. Hal ini menunjukkan bahwa dari segi penurunan nilai $\mathrm{C} / \mathrm{N}$, fungsi faktor laju aerasi dan nilai $\mathrm{C} / \mathrm{N}$ awal bersifat sinergis sehingga jika diterapkan bersama-sama akan meningkatkan efektivitas, terutama pada $\mathrm{C} / \mathrm{N}$ awal 35 . Namun penerapan laju aerasi dan nilai $\mathrm{C} / \mathrm{N}$ awal secara bersamaan untuk $\mathrm{C} / \mathrm{N}$ awal selain 35 tidak dapat meningkatkan efektivitas, sehingga untuk $\mathrm{C} / \mathrm{N}$ awal selain 35 faktor yang perlu diterapkan agar dapat meningkatkan efektivitas adalah salah satu di antara keduanya.

Berdasarkan hasil uji Duncan, nilai $\mathrm{C} / \mathrm{N}$ pada minggu ke-0 berbeda nyata dengan nilai $\mathrm{C} / \mathrm{N}$ pada minggu ke-2, minggu ke-4, serta minggu ke-6 dan 8. Tidak ada perbedaan nyata antara nilai $\mathrm{C} / \mathrm{N}$ pada minggu ke-6 dan 8. Hal ini menunjukkan bahwa campuran limbah padat beltpress dan jerami padi cenderung mulai stabil setelah minggu ke-6. Dengan demikian dapat disimpulkan bahwa fase aktif proses pengomposan limbah padat beltpress dan jerami padi berakhir setelah 6 minggu.

\section{Karakteristik Produk Kompos} Karakteristik Fisik

Karakteristik fisik kompos yang diamati meliputi warna, tekstur dan bau. Selama pengomposan, warna bahan berubah menjadi gelap. Hal ini disebabkan oleh terbentuknya humus dari dekomposisi lignin, polisakarida dan senyawa yang mengandung nitrogen (Varadachari dan Ghosh,
1984). Kematangan kompos dikatakan tercapai apabila warnanya telah menjadi coklat kehitaman (Alberta, 1999). Sementara kompos yang belum matang memiliki warna lebihmuda karena bahan organik belum terdegradasi sepenuhnya (Lekammudiyanse dan Gunatilake, 2010).

Berdasarkan hasil penelitian, semakin tinggi laju aerasi, warna kompos yang dihasilkan semakin gelap. Hal ini menunjukkan semakin tinggi laju aerasi, pembentukan humus juga semakin tinggi sehingga kematangan kompos lebih cepat tercapai. Selain itu, semakin tinggi nilai $\mathrm{C} / \mathrm{N}$ awal, warna kompos yang dihasilkan semakin muda. Hal ini disebabkan oleh lebih banyaknya kandungan jerami padi pada $\mathrm{C} / \mathrm{N}$ awal yang lebih tinggi, sehingga waktu yang dibutuhkan untuk mendegradasinya secara keseluruhan lebih banyak daripada bahan yang memiliki kandungan jerami padi lebih sedikit.Syarat warna kompos yang tertera dalam SNI 19-7030-2004 adalah kehitaman. Oleh karena itu perlakuan yang sesuai SNI dari segi warna adalah $\mathrm{C} / \mathrm{N}$ awal 25 dengan laju aerasi 0,4 dan 0,8 $\mathrm{L} /$ menit.kg bahan kering, serta $\mathrm{C} / \mathrm{N}$ awal 30 dengan laju aerasi $0,8 \mathrm{~L} / \mathrm{menit} . \mathrm{kg}$ bahan kering.

Dari segi ukuran partikel, ukuran partikel kompos dengan laju aerasi $0,8 \mathrm{~L} /$ menit.kg bahan kering lebih kecil daripada yang lainnya, sedangkan kompos dengan laju aerasi $0 \mathrm{~L} /$ menit.kg bahan kering lebih besar daripada yang lainnya. Menurut Murbandono (1993), degradasi akan meningkat dengan adanya pemberian aerasi. Adanya peningkatan degradasi bahan akan mengecilkan ukuran partikel bahan dan meningkatkan pembentukan humus, sehingga semakin membentuk tekstur yang halus dan menyerupai tanah.

Berdasarkan hasil penelitian juga, semakin tinggi nilai $\mathrm{C} / \mathrm{N}$ awal, semakin besar ukuran partikel kompos yang dihasilkan. Hal ini disebabkan semakin banyak kandungan jerami padi pada perlakuan $\mathrm{C} / \mathrm{N}$ awal yang lebih tinggi. Jerami padi yang berperan sebagai sumber karbon dan bulking agent pada pengomposan limbah padat beltpress memiliki ukuran yang lebih besar daripada limbah padat beltpress. Semakin banyak jerami padi yang dikandung pada suatu $\mathrm{C} / \mathrm{N}$ awal, semakin besar massa dan volumenya, sehingga dalam kurun waktu pengomposan yang sama ukuran partikel yang terbentuk lebih besar. Berdasarkan SNI 19-70302004, ciri kematangan kompos dari segi ukuran partikel adalah berkisar 0,55-25 mm. Seluruh perlakuan memenuhi syarat SNI karena sebelum dikomposkan jerami telah dicacah menjadi ukuran $25 \mathrm{~mm}$ untuk mempercepat pengomposan. Oleh karena itu perlakuan paling optimal untuk ukuran partikel adalah perlakuan yang memiliki ukuran partikel terkecil, yaitu perlakuan $\mathrm{C} / \mathrm{N}$ awal 25 dengan laju aerasi $0,8 \mathrm{~L} /$ menit.kg bahan kering.

Dari segi bau, kompos dengan laju aerasi 0,8 L/menit.kg bahan kering bau tanah, sementara pada laju aerasi lainnya adalah bau sangit. Bau 
disebabkan oleh adanya senyawa asam-asam lemak, ammonia dan senyawa lain yang mengandung nitrogen, keton, senyawa aromatik, serta senyawa yang mengandung sulfur organik dan anorganik (Epstein, 1997). Senyawa tersebut dihasilkan dari proses degradasi anaerobik (Lekammudiyanse dan Gunatilake 2010). Bau tanah (earthy) pada akhir pengomposan disebabkan adanya produksi metabolit sekunder seperti geosmin dan metil iso-borneol oleh mikroorganisme (Li et al., 2004). Menurut Zhu (2000), aerasi dapat mengurangi bau dengan memberikan oksigen terlarut untuk bakteri aerobik sehingga aktif menguraikan senyawa berbau.Hal ini menunjukkan laju aerasi $0,8 \mathrm{~L} /$ menit.kg bahan kering memberikan oksigen dalam jumlah cukup. Hal ini diperkuat oleh Zhang (2008) bahwa laju aerasi optimal untuk mengurangi bau adalah 0,6 L/menit.kg bahan kering dengan sistem aerasi intermiten. Sementara itu nilai $\mathrm{C} / \mathrm{N}$ awal tidak mempengaruhi bau kompos. Berdasarkan SNI 197030-2004, kompos matang berbau tanah. Perlakuan yang memenuhi syarat tersebut adalah $\mathrm{C} / \mathrm{N}$ awal 25 dan 35 dengan laju aerasi $0,8 \mathrm{~L} /$ menit.kg bahan kering.

Perlakuan terbaik untuk karakteristik fisik kompos dipilih berdasarkan kesesuaiannya dengan SNI 19-7030-2004 yaitu memiliki warna kehitaman, tekstur seperti tanah dan berbau tanah. Perlakuan terbaik dari segi fisik kompos yaitu $\mathrm{C} / \mathrm{N}$ awal 25 dengan laju aerasi $0,8 \mathrm{~L} / \mathrm{menit} . \mathrm{kg}$ bahan kering.

\section{Karakteristik Kimia}

Hasil pengujian karakteristik kompos secara kimia yang meliputi kadar air, kadar karbon, total kjedahl nitrogen, nilai $\mathrm{C} / \mathrm{N}, \mathrm{pH}$ dan suhu disajikan pada Tabel 3. Tabel 3 menunjukkan bahwa hampir seluruh perlakuan memenuhi syarat SNI 197030-2004 dari parameter-parameter tersebut. Namun terdapat beberapa perlakuan yang tidak memenuhi syarat. Dari segi kadar air, hanya perlakuan $\mathrm{C} / \mathrm{N}$ awal 25 pada laju aerasi 0,4 dan 0,8 L/menit.kg bahan kering yang hampir memenuhi syarat SNI. Dari segi nilai $\mathrm{C} / \mathrm{N}$, perlakuan $\mathrm{C} / \mathrm{N}$ awal 35pada laju aerasi $0 \mathrm{~L} /$ menit.kg bahan kering tidak memenuhi syarat. Dari segi suhu, perlakuan pada $\mathrm{C} / \mathrm{N}$ awal 25 dengan laju aerasi $0 \mathrm{~L} /$ menit.kg bahan kering, dan semua perlakuan $\mathrm{C} / \mathrm{N}$ awal pada laju aerasi 0,4 L/menit.kg bahan kering tidak memenuhi syarat. Dari segi nilai pH kompos semua perlakuan tidak memenuhi syarat SNI. Dengan demikian, diketahui bahwa diperlukannya peningkatan modifikasi proses agar diperoleh kompos yang sesuai dengan SNI.

\section{Pemilihan dan Pengujian Karakteristik Lanjutan Perlakuan Terbaik \\ Pemilihan Perlakuan Terbaik}

Parameter penilaian perlakuan terbaik adalah parameter yang nilainya berubah selama pengomposan, serta parameter mutu kompos secara fisik dan kimia. Perlakuan terbaik dipilih berdasarkan jumlah parameter yang paling banyak memenuhi syarat SNI. Berdasarkan hasil tabulasi, diketahui bahwa perlakuan $\mathrm{C} / \mathrm{N}$ awal 25 dengan laju aerasi $0,8 \mathrm{~L} /$ menit.kg bahan kering merupakan perlakuan yang paling memenuhi syarat SNI 197030-2004.

\section{Pengujian Karakteristik Lanjutan Perlakuan Terbaik Kompos dengan perlakuan terbaik yaitu} $\mathrm{C} / \mathrm{N}$ awal 25 dengan laju aerasi $0,8 \mathrm{~L} /$ menit.kg bahan kering secara keseluruhan memenuhi syarat SNI 19-7030-2004 dari segi kandungan kimia. Selain itu, dengan metode TPC, bakteri Escherichia coli serta Salmonella sp tidak ditemukan. Menurut EPA (1999), pada suhu pengomposan di atas $55^{\circ} \mathrm{C}$ terjadi eliminasi mikroorganisme pathogen. Namun perlakuan $\mathrm{C} / \mathrm{N}$ awal 25 dengan laju aerasi 0,8 $\mathrm{L} /$ menit.kg bahan kering hanya mencapai $40^{\circ} \mathrm{C}$. Droffiner dan Brinton (1995) menyatakan bahwa mekanisme untuk menghilangkan mikroorganisme patogen selama pengomposan bersifat kompleks dan tidak hanya dari hasil tingginya suhu pengomposan. Hal ini dibuktikan oleh hasil penelitian Larney dan Blackshaw (2003) bahwa lebih dari 99,9\% dari E.coli mati pada 7 hari pertama pengomposan dengan suhu berkisar $33,5-41,5^{\circ} \mathrm{C}$. Hal ini dapat terjadi karena kerusakan patogen secara termal juga tergantung pada faktor-faktor lain selain suhu, yaitu kadar air, kadar amonia bebas, durasi perlakuan panas dan keberadaan mikroorganisme lain serta senyawa intermediet yang dapat meningkatkan inaktivasi patogen (Burton dan Turner, 2003).

Tabel 3. Hasil analisis mutu kompos secara kimia

\begin{tabular}{|c|c|c|c|c|c|c|c|c|c|c|c|}
\hline \multirow[t]{2}{*}{ Parameter Mutu } & \multicolumn{3}{|c|}{$\begin{array}{c}\text { 0 L/menit.kg bahan } \\
\text { kering }\end{array}$} & \multicolumn{3}{|c|}{$\begin{array}{c}\text { 0,4 L/menit.kg bahan } \\
\text { kering }\end{array}$} & \multicolumn{3}{|c|}{$\begin{array}{c}\text { 0,8 L/menit.kg bahan } \\
\text { kering }\end{array}$} & \multicolumn{2}{|c|}{$\begin{array}{l}\text { SNI 19-7030- } \\
2004\end{array}$} \\
\hline & 25 & 30 & 35 & 25 & 30 & 35 & 25 & 30 & 35 & Min & Max \\
\hline Kadar air (\%) & 54,32 & 57,69 & 61,52 & 50,94 & 54,28 & 57,61 & 50,10 & 55,56 & 55,18 & - & 50 \\
\hline Kadar karbon $(\%)$ & 15,91 & 14,14 & 11,87 & 17,23 & 13,88 & 12,15 & 16,58 & 12,69 & 12,57 & 9,8 & 32 \\
\hline Total nitrogen $(\%)$ & 0,98 & 0,73 & 0,47 & 1,15 & 0,74 & 0,64 & 1,11 & 0,79 & 0,65 & 0,4 & - \\
\hline Nilai C/N & 16,19 & 19,41 & 25,20 & 14,98 & 18,77 & 18,91 & 14,94 & 16,00 & 19,22 & 10 & 20 \\
\hline Nilai pH & 8,58 & 8,6 & 8,33 & 8,7 & 8,5 & 8,58 & 8,8 & 8,6 & 8,55 & 6,8 & 7,49 \\
\hline Suhu $\left({ }^{\circ} \mathrm{C}\right)$ & 30,7 & 29,7 & 28,7 & 31,3 & 32,2 & 31,2 & 29,7 & 29,0 & 27,8 & 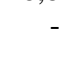 & $\begin{array}{r}\text { Suhu air } \\
\text { tanah }\end{array}$ \\
\hline
\end{tabular}




\section{KESIMPULAN DAN SARAN}

\section{Kesimpulan}

Kompos dapat dibuat dari campuran limbah padat beltpress dan jerami padi dengan metode aerated static pile. Pada penelitian ini nilai $\mathrm{C} / \mathrm{N}$ awal dan laju aerasi mempengaruhi kondisi pengomposan seperti suhu dan kadar air, sehingga pada akhirnya juga mempengaruhi penurunan nilai $\mathrm{C} / \mathrm{N}$, tetapi tidak mempengaruhi nilai $\mathrm{pH}$. Semakin rendah nilai $\mathrm{C} / \mathrm{N}$ awal dan semakin tinggi laju aerasi, semakin cepat mencapai nilai $\mathrm{C} / \mathrm{N}$ yang sesuai dengan SNI 19-7030-2004. Perlakuan terbaik untuk pengomposan limbah padat beltpress dan jerami padi berdasarkan kesesuaian nilai parameter yang diamati dengan SNI 19-7030-2004 adalah C/N awal 25 dengan laju aerasi $0,8 \mathrm{~L} /$ menit.kg bahan kering. Kompos yang dihasilkan dari perlakuan tersebut mencapai $\mathrm{C} / \mathrm{N}$ sesuai SNI mulai minggu ke-2 dan memenuhi syarat SNI 19-7030-2004 bagian unsur makro, unsur mikro dan unsur lainnya, tetapi tidak memenuhi syarat nilai $\mathrm{pH}$ dan kadar air pada minggu ke-8 pengomposan.

\section{Saran}

Nilai $\mathrm{pH}$ kompos seluruh perlakuan lebih tinggi dari yang disyaratkan SNI 19-7030-2004. Hal ini menunjukkan perlu adanya peningkatan intensitas pemberian aerasi agar terjadi oksidasi amonium menjadi nitrat yang lebih tinggi. Selain itu perlu dikaji lebih lanjut mengenai jumlah air yang optimal untuk ditambahkan selama pengomposan agar tidak terjadi kondisi anaerobik.

\section{DAFTAR PUSTAKA}

Abbasi PA, JAl-Dahmani, Sahin F, Hoitink HAJ, Miller SA. 2002. Effect of Compost Amendments on Disease Severity and Yield of Tomato in Conventional and Organic Production Systems. Plant Dis. 86:156- 161.

Agastirani G. 2011. Kajian pengaruh aerasi dan konsentrasi sludge terhadap laju penurunan $\mathrm{C} / \mathrm{N}$ pada proses co-composting blotong dan sludge industri gula. [Skripsi]. Bogor (ID) : Institut Pertanian Bogor.

Alberta. 1999. Leaf and Yard Waste Composting Manual. Edmonton (CA): Alberta Environment. 33-34.

Asian Development Bank. 2011. Toward Sustainable Municipal Organic Waste Management in South Asia: A Guidebook for Policy Makers and Practitioners. Mandaluyong (PH) : Asian Development Bank.

[AOAC] Association of Official Analytical Chemists. 1984. Official Methods of Analysis of the Association of Official Analytical Chemists $14^{\text {th }} E d$. Washington DC (US) : Association of Official Analytical Chemists.
Bari QH. 1999. Effect of Different Modes of Aeration on Composting of Solid Waste in A Closed System. [Thesis]. Hongkong : The University of Hongkong.

[BSN] Badan Standardisasi Nasional. 2004. SNI 066989.11-2004 Air dan Air Limbah - Bagian 11 : Cara Uji Derajat Keasaman ( $p H)$ dengan Menggunakan Alat pH-meter. Tangerang (ID): Badan Standardisasi Nasional.

[BSN] Badan Standardisasi Nasional. 2004. SNI 197030-2004 Spesifikasi Kompos dari Sampah Organik Domestik. Tangerang (ID) : Badan Standardisasi Nasional.

Beck-Friis B, Smårs S, Jönsson H, Eklind Y, Kirchmann H. 2003. Composting of sourceseparated household organics at different oxygen levels: gaining an understanding of the emission dynamics. Compost Sci Utilization. $11: 41-50$.

Bernal MP, Sanchez-Monedero MA, Paredes C, Roig A. 1998. Carbon mineralization from organic wastes at different composting stages during their incubation with Soil. Agricul, Ecosys Environ. 69 (3) : 175-189.

Bertoldi M, Vallini G, dan Pera A. 1983. The biology of composting. Waste Mgmt Res. 1 : 157-176.

Bishop PL dan Godfrey C. 1983. Nitrogen variations during sludge composting. Bio Cycle. 24 : 3439.

Bolan NS, Adriano DC, dan Curtin D. 2003. Soil Acidification and LimingInteractions with Nutrient and Heavy Metal Transformation and Bioavailability. Adv in Agro. 78 : 215272.

Burton CH dan Turner C. 2003. Manure Magement. Treatment Strategies for Sustainable Agriculture. Bedford (UK) : Lister \& Durling Printers.

Cahyani DA. 2013. Laju aerasi pada pengomposan limbah sayuran menggunakan komposter dengan pengaduk putar [Skripsi]. Banjarnegara (ID) : Agroteknologi Politeknik Banjarnegara.

Dalzell H, Biddletone AJ, Gray KR, Thurairajan K. 1987. Pengolahan Tanah: Produksi dan Penggunaan Kompos dalam Limbah Padat di Indonesia. Jakarta (ID) : Yayasan Obor Indonesia.

Diaz MJ, Madejon E, Lopez F, Lopez R, Cabrera F. 2002. Optimization of the rate vinasse/grape marc for co-composting process. Process Biochem. 37 : 1143-1150.

Djaja W. 2008. Langkah Jitu Membuat Kompos dari Kotoran Ternak \& Sampah. Jakarta (ID) : PT. Agro Media Pustaka.

Djuarnani N, Kristian, dan Setiawan BS. 2005. Cara Cepat Membuat Kompos. Jakarta (ID) : AgroMedia Pustaka. 
Droffiner ML dan Brinton WF. 1995. Survival of E.coli and salmonella populations in aerobic thermophilic composts as measured with dna gene probes. Pub Med. 197(5):387-397.

Eklind Y dan Kirchmann H. 2000. Composting and storage of organic household waste with different litter amendmentsii: nitrogen turnover and losses. Biores Technol. 74(2):125-133.

[EPA] Environmental Protection Agency. 1999. Odor Management Practices for Composting Facilities. Ohio Columbus (US) : Environmental Protection Agency.

Epstein E. 1997. The Science of Composting. Pennsylvania (US) : Technomic Publishing Company.

Formentini DF, Costanzi RN, Hashisuca AM, Paulillo G, Neto ARP, Morais J. 2010. Water Conservation and Reuse in Poultry Slaughterhouse of Matelandia-Pr Brazil - A Case Study. Cascavel (BR) : LAR Poultry Slaughterhouse.

Gaur AC. 1983. A Manual of Rural Composting. Rome (IT) : FAO United Nation.

Girovich MJ. 1996. Biosolids Treatment and Management : Process for Beneficial Use. New York (US) : Marcel Dekker Inc.

Golueke CG. 1972. Composting : A Study of The Process and Its Principles. Pennsylvania (US) : Rodale Press.

Guo R, Guoxue Li, Tao Jiang, F Schuchardt, Tongbin Chen, Yuanqiu Zhao, Yujun Shen. 2012. Effect of Aeration Rate, C/N Ratio, and Moisture Content on the Stability and Maturity of Compost. Bioresource Technology. 112 : 171-178.

Harahap D. 2010. Laju dekomposisi secara aerobik dan kualitas kompos dari berbagai residu tanaman dengan penambahan berbagai dekomposer. [Skripsi]. Medan (ID) : Universitas Sumatera Utara.

Haug RT. 1980. Compost Engineering Principles and Practices. Michigan (US) : Ann Arbor Science Publishers.

Herdiyantoro D. 2010. Pengomposan: Mikrobiologi dan Teknologi Pengomposan. Bandung (ID) : Jurusan Ilmu Tanah Fakultas Pertanian Universitas Padjajaran

Hermawan A. 2015. Teknologi Tepat Guna untuk Optimalisasi Pekarangan. Ungaran (ID) : Balai Pengkajian Teknologi Pertanian Jawa Tengah.

Indrasti NS. 2015. Teknologi Pengomposan. Bogor (ID) : IPB Press.

Isroi. 2008. Kompos. Bogor (ID) : Balai Penelitian Bioteknologi Perkebunan Indonesia.

[JICA] Japan International Cooperation Agency. Methods of Soil Chemical Analysis. Indonesia - Japan Join Food Crop Research
Program. Bogor (ID) : Badan Penelitian dan Pembangunan Pertanian.

Karki AB dan Dixit K. 1984. Biogas Fieldbook. Khatmandu (NP) : Sahayogi Press.

Kleidon A. 2005. Non-Equilibrium Thermodynamics and The Production of Entropy. Germany : Springer-Verlag Berlin.

Larney FJ dan Blackshaw RE. 2003. Weed seed viability in composted beef cattle feedlot manure. J. Environ Qual. 32: 1105-1113.

Lekammudiyanse LMMU dan SK Gunatilake. 2010. Efficiency of the household compost bin as a waste management technique in sri lanka (A Case study in gampaha municipal council area). Int J Basic Appl Sci. 10(1): 54-59.

LiHF, ImaiT, Ukita M, SekineM, HiguchiT. 2004. Compoststability assessment using a secondary metabolite: geosmin. Environ Technol. 25 : 1305-1312.

Metcalf E. 1991. Wastewater Engineering Treatment Disposal Reuse. New York (US) : McGrawHill.

Moore PA, Huff WEJ, Daniel TC, Edward DR,Saucer TC.1997. Effect of Aluminium Sulfate on Ammonia Fluxes from Poultry Litter in Commercial Broiler Houses. Di dalam : Proceedings of the 5th International Symposium on Livestock Environment, Transactions of the ASAE 2, 883-891.

Mulder M. 1996. Basic Principles of Membrane Technology $2^{\text {nd }}$ Edition. Dordrecht (NL) : Kluwer Academic Publishers.

Murbandono HS. 1993. Membuat Kompos. Jakarta : Penebar Swadaya.

O'leary P. 1995. Decision-Maker's Guide to Solid Waste Management $2^{\text {nd }} E d$. Washington DC (US) : [EPA] Environmental Protection Agency.

Panda H. 2013. Handbook on Organic Farming and Processing. New Delhi : Asia Pasific Business Press.

Rynk R, M van de Kamp, Wilson GB, Singley ME, Richard TL, Kolega JJ, Gouin FR, Jr. Laliberty L, Kay D, Murphy DW, Hoitink HAJ, Brinton WF. 1992. On-Farm Composting Handbook. New York (US) : Northeast Regional Agricultural Engineering Service.

Rynk R. 2003. Large animal mortality composting goes mainstream. Bio Cycle. 44(6) : 44-49.

Stryer L. 1995. Biochemistry. $4^{\text {th }}$ ed.. New York (US) : W. H. Freeman and Company.

Suler DJ dan Finstein MS. 1977. Effect of temperature, aeration, and moisture on $\mathrm{CO} 2$ formation in bench-scale, continuously thermophilic composting of solid waste. Appl Environ Microbiol. 33 (2) : 345-350.

Sundberg C, Smars S, dan Jonsson H. 2004. Low pH as an inhibiting factor in the transformation 
from mesophilic to thermophilic phase in composting. Biores Technol. 95 : 145-150.

Varadachari V dan Ghosh K. 1984. Humus formation. Plant Soil. 77 : 305-313.

Weast RC, Lide DR, Astle MJ, BeyerWH. 1990. CRC Handbook of Chemistry and Physics. Boca Raton (US) : CRC Press.
Zhang W. 2008. Preventive control of ammonia and odor emissions during the active phase of poultry manure composting. [Thesis]. Vancouver (CA): The University of British Columbia.

ZhuJ. 2000. A review of microbiology in swine manure odor control. Agricul Ecosys Environ. 78:93-106. 